E3S Web of Conferences 1, 34004 (2013)

DOI: $10.1051 / \mathrm{e} 3$ sconf/20130134004

(C) Owned by the authors, published by EDP Sciences, 2013

\title{
Polonium ${ }^{210} \mathrm{Po}$, uranium $\left({ }^{234} \mathrm{U},{ }^{238} \mathrm{U}\right)$ and plutonium $\left({ }^{238} \mathrm{Pu},{ }^{239+240} \mathrm{Pu}\right)$ bioaccumulation in marine birds
}

\author{
D. I. Strumińska-Parulska $^{1}$, A. Boryło ${ }^{1}$, B. Skwarzec $^{1}$ and J. Fabisiak ${ }^{2}$ \\ ${ }^{1}$ University of Gdańsk, Faculty of Chemistry, Sobieskiego 18/19, 80-952 Gdańsk, Poland, \\ strumyk@chem.univ.gda.pl \\ ${ }^{2}$ Naval Academy, Śmidowicza 61, 81-103 Gdynia, Poland
}

\begin{abstract}
The aim of this work was the determination of ${ }^{210} \mathrm{Po},{ }^{234} \mathrm{U},{ }^{238} \mathrm{U},{ }^{238} \mathrm{Pu}$ and ${ }^{239+240} \mathrm{Pu}$ concentration in marine birds which permanently or temporally live in the southern Baltic Sea coast. We chose 11 species of seabirds: three species permanently residing at southern Baltic Sea, four species of wintering birds and three species of migrating birds. The results show that analyzed radionuclides are non-uniformly distributed in the marine birds. The highest activities of ${ }^{210} \mathrm{Po}$ were observed in feathers, muscles and liver. The highest uranium content was found in liver, rest of viscera and feathers, while plutonium in the digestion organs and feathers. Omnivore seabirds accumulated more polonium, plutonium than species that feed on fish, while herbivore seabirds accumulated more uranium than carnivore.
\end{abstract}

Keywords: polonium, uranium, plutonium, marine birds, bioaccumulation, Baltic Sea

\section{Introduction}

The estimation of the size of contamination caused by alpha radioactive elements in the natural environment and their effects on living organisms is one of the most important issues of the radiochemical and radiological protection. Among alpha radioactive elements present in the environment, polonium plays an important role because ${ }^{210}$ Po belongs to the most radiotoxic nuclides to human beings. The most important natural source of ${ }^{210} \mathrm{Po}$ in the environment is uranium decay series starting from ${ }^{238} \mathrm{U}$. Polonium is strongly accumulated in the marine biota and for this reason it is an important source of radiation dose in the body of marine animals (Skwarzec, 1995). The intensive studies on the occurrence and distribution of ${ }^{210} \mathrm{Po}$ in the ecosystem of the southern Baltic help to recognize mechanisms and circulation of polonium in the environment. Uranium occurs naturally in the Earth's crust and occurs in much higher concentrations, along with thorium and rare earth element in the area where monazite sand prevails (Skwarzec, 1995). The average concentration of uranium in the Earth's crust is $4 \cdot 10^{-4} \%$. The isotope ${ }^{238} \mathrm{U}$ is the parent nuclide of the radioactive decay uranium-radium series. Uranium is relatively highly toxic to human, both chemically and radiologically (its progeny are highly radioactive). Various components of uranium can penetrate the blood from alveolus pockets in the lungs or through the gastrointestinal tract. The presence of uranium in the body can cause damage to the kidney, leading to nephritis (Tutu et al., 2005). Most of uranium in the environment is located in terrigenic materials (Skwarzec et al., 2006). Natural uranium concentration in rivers varies linearly with salinity (Skwarzec, 1995). Man-made plutonium is widespread all over the world, takes part in geochemical circulation and accumulates in the food chain. The main source of plutonium in Poland and the Baltic Sea, before the Chernobyl accident, was global fallout from nuclear weapons testing. Other sources of plutonium, e.g. releases from the spent fuel facilities at Sellafield (UK) and Cap de la Hague (France), are less important (Skwarzec, 1995; Strumińska-Parulska and Skwarzec, 2010). Plutonium can be accumulated in the marine biota and for this reason it is an important source of radiation dose in the body of marine animals (Skwarzec,1995). The total ${ }^{239+240} \mathrm{Pu}$ amount in the Baltic Sea was estimated at $15.2-24.2 \mathrm{TBq}$ and over $90 \%$ is deposited in sediments, about $0.2 \mathrm{TBq}$ exists in water and only a few GBq is accumulated in biota (Salo et al., 1986).

Birds are characterized by high body temperature and intensive metabolism what cause high daily food 
requirement (Tomiałojć and Stawarczyk, 2003). Most of them are double-environment animals. That is why they are an important part of the ecosystems. Seabirds are a very important element of the trophic chain of marine ecosystem. Particularly the birds' feathers are often used as a bioindicator of metal contamination of marine and air environment (Burger and Gochfeld, 1997). Knowledge on the polonium, uranium and plutonium distribution in birds is very poor. From over 9000 species of birds in the world, 438 species have been registered in Poland, of which 230 birds live in the Polish area of the Baltic Sea (Tomiałojć and Stawarczyk, 2003). The aim of this work was determination of ${ }^{210} \mathrm{Po}$, ${ }^{234} \mathrm{U},{ }^{238} \mathrm{U},{ }^{238} \mathrm{Pu}$ and ${ }^{239+240} \mathrm{Pu}$ concentration in marine birds from the southern Baltic Sea coast as well as recognition of their accumulation in different organs and tissues analyzed birds. Moreover, the studies can help to recognize the radionuclides sources in marine birds as well as their connection with their diet and living habits.

\section{Material and Methods}

Among bird species registered in the Polish area of the southern Baltic Sea, there are three main groups: sea birds which permanently reside, principally in Gdansk Bay and Puck Bay, wintering birds and migratory birds. The following sea birds were collected for research: 1 . seabirds which permanently reside in the southern Baltic Sea - tufted duck (Aythya fuligula), eurasian coot (Fulica atra), great cormorant (Phalacrocorax carbo); 2. wintering birds - common eider (Somateria mollissima), velvet scoter (Melanitta fusca), black guillemot (Cepphus grylle), long-tailed duck (Clangula hyemalis), 3. migratory birds - razorbill (Alca torda), common guillemot (Uria aalge), red-throated diver (Gavia stellata) (Skwarzec and Fabisiak, 2007; Boryło et al., 2010; Strumińska-Parulska et al., 2011). The fresh samples were weighted, homogenized and digested using $65 \% \mathrm{HNO}_{3}$ with a ${ }^{209} \mathrm{Po}(50 \mathrm{mBq}),{ }^{232} \mathrm{U}(32.5 \mathrm{mBq})$ and ${ }^{242} \mathrm{Pu}(5 \mathrm{mBq})$ spikes added as a yield tracers. The radiochemical method allows $\mathrm{Po}, \mathrm{U}$ and $\mathrm{Pu}$ determination from the same sample (Skwarzec, 1995, Skwarzec and Fabisiak, 2007; Skwarzec, 2009, Boryło et al., 2010; Strumińska-Parulska et al., 2011). After radiochemical preparation, the activities of ${ }^{210} \mathrm{Po},{ }^{234} \mathrm{U}$, ${ }^{238} \mathrm{U},{ }^{238} \mathrm{Pu}$ and ${ }^{239+240} \mathrm{Pu}$ radionuclides were measured separately using alpha spectrometer (Alpha Analyst, Canberra Packard) equipped with PIPS detectors. The accuracy and precision of the radiochemical method were evaluated using IAEA reference materials and estimated at less than $7 \%$.

\section{Results and Discussion}

${ }^{210} \mathrm{Po}$

The results of ${ }^{210} \mathrm{Po}$ concentration in tissues and organs of marine birds from the southern Baltic Sea are shown in Tab. 1. The data show that ${ }^{210} \mathrm{Po}$ is non-uniformly distributed in tissues and organs of the seabirds. The highest ${ }^{210} \mathrm{Po}$ concentrations were mostly in liver and ranged from $0.16 \mathrm{~Bq} \mathrm{~kg}^{-1} \mathrm{ww}$ in tufted duck to $18.90 \mathrm{~Bq}$ $\mathrm{kg}^{-1} \mathrm{ww}$ in long-tailed duck. The high ${ }^{210}$ Po concentrations were also observed in feathers and ranged from $0.47 \mathrm{~Bq}$ $\mathrm{kg}^{-1} \mathrm{ww}$ in tufted duck to $5.70 \mathrm{~Bq} \mathrm{~kg}{ }^{-1}$ ww in great cormorant. Among the analyzed species of sea birds, the highest ${ }^{210} \mathrm{Po}$ concentration in whole organism was measured in long-tailed duck at $3.54 \mathrm{~Bq} \mathrm{~kg}^{-1}$ ww (Tab. 1). The ${ }^{210} \mathrm{Po}$ concentration in tissues and organs of this bird was much higher than in the rest of the analyzed species of sea birds. The analysis of diet and feeding habit showed that it is a very important aspect of ${ }^{210} \mathrm{Po}$ accumulation in tissues and organs of sea birds from the southern Baltic Sea. The ${ }^{210}$ Po concentration was higher in omnivore marine birds as as long-tailed duck, velvet scoter, black guillemot and eurasian coot feeding on crustaceans, mollusks, fish, plants and algae. The ${ }^{210}$ Po concentration was lower in tissues and organs of predatory fish-feeding seabirds as great cormorant and common guillemot or herbivore birds as tufted duck. The results of our studies show that the ${ }^{210}$ Po concentration was higher in wintering sea birds such as long-tailed duck, black guillemot and velvet scoter. The differences in accumulation of trace elements in birds are also connected with diet and place of residence (Skwarzec and Fabisiak, 2007).

\section{${ }^{234} U$ and ${ }^{238} U$}

The results of ${ }^{234} \mathrm{U}$ and ${ }^{238} \mathrm{U}$ concentration as well as total uranium concentration in organs and tissues of analyzed marine birds were presented in Table 1. The obtained results indicated that uranium is non-uniformly distributed in tissues and organs of analyzed marine birds. The highest values of ${ }^{234} \mathrm{U}$ and ${ }^{238} \mathrm{U}$ were measured in rest of viscera: from 46.6 and $48.3 \mathrm{mBq} \mathrm{kg}^{-1} \mathrm{ww}$ in razorbill to 919 and $921 \mathrm{mBq} \mathrm{kg}^{-1} \mathrm{ww}$ in tufted duck and in feathers as well: from 68.7 and $76.7 \mathrm{mBq} \mathrm{kg}^{-1} \mathrm{ww}$ in eurasian coot to 341 and $294 \mathrm{mBq} \mathrm{kg}^{-1} \mathrm{ww}$ in great cormorant. Further studies showed the maximum uranium concentrations were found in herbivorous as eurasian coot and tufted duck while lower were estimated for predatory as razorbill and great cormorant. (Tab. 1). Food is a very important source of uranium in marine birds. The uranium concentration was higher for visitant birds in region of the Gulf of Gdańsk in period from October to April (tufted duck and eurasian coot). On account of birds moulting, we observed higher uranium concentration for species, which permanently live on the land (great cormorant, common eider, eurasian coot).

The obtained results are in agreement to values reported for marine organisms in southern Baltic Sea (Skwarzec, 1995). Bioaccumulation of uranium by marine birds is slight, because his radionuclide is quickly removed from organism. 
Tab.1 Polonium ${ }^{210} \mathrm{Po}$, uranium ${ }^{234} \mathrm{U}$ and ${ }^{238} \mathrm{U}$ and plutonium ${ }^{238} \mathrm{Pu}$ and ${ }^{239+240} \mathrm{Pu}$ concentrations in organs and tissues of analyzed seabirds (Skwarzec and Fabisiak, 2007; Boryło et al., 2010; Strumińska-Parulska et al., 2011)

\begin{tabular}{|c|c|c|c|c|c|c|c|c|c|c|}
\hline \multirow{3}{*}{$\begin{array}{l}\text { Organ, } \\
\text { tissue }\end{array}$} & \multicolumn{10}{|c|}{ Concentration } \\
\hline & ${ }^{210} \mathrm{Po}$ & ${ }^{234} \mathrm{U}$ & ${ }^{238} \mathrm{U}$ & ${ }^{238} \mathrm{Pu}$ & ${ }^{239+240} \mathrm{Pu}$ & ${ }^{210} \mathrm{Po}$ & ${ }^{234} \mathrm{U}$ & ${ }^{238} \mathrm{U}$ & ${ }^{238} \mathrm{Pu}$ & ${ }^{239+240} \mathrm{Pu}$ \\
\hline & {$\left[\mathrm{Bq} \mathrm{kg}^{-1} \mathrm{ww}\right]$} & \multicolumn{2}{|c|}{$\left[\mathrm{mBq} \mathrm{kg}^{-1} \mathrm{ww}\right]$} & \multicolumn{2}{|c|}{$\left[\mathrm{mBq} \mathrm{kg}^{-1} \mathrm{ww}\right]$} & {$\left[\mathrm{Bq} \mathrm{kg}^{-1} \mathrm{ww}\right]$} & \multicolumn{2}{|c|}{$\left[\mathrm{mBq} \mathrm{kg}{ }^{-1} \mathrm{ww}\right]$} & \multicolumn{2}{|c|}{$\left[\mathrm{mBq} \mathrm{kg}^{-1} \mathrm{ww}\right]$} \\
\hline & \multicolumn{5}{|c|}{ Great cormorant (Phalacrocorax carbo) $(\mathrm{n}=1)$} & \multicolumn{5}{|c|}{ Eurasian coot (Fulica atra $)(\mathrm{n}=1)$} \\
\hline Liver & 0.29 & 15.7 & 16.29 & 0.28 & 2.21 & - & - & -1 & - & - \\
\hline Muscle & 0.05 & 3.35 & 3.45 & 0.06 & 0.19 & 0.34 & 42.5 & 41.9 & 0.17 & 0.34 \\
\hline Feathers & 5.70 & 341 & 294 & 0.10 & 0.37 & 2.99 & 68.7 & 76.7 & 0.15 & 0.52 \\
\hline Skeleton & 0.22 & 10.4 & 11.3 & 0.02 & 0.05 & 3.38 & 40.5 & 41.7 & 0.05 & 0.42 \\
\hline Skin & 0.35 & 76.9 & 65.6 & 0.03 & 0.13 & 0.49 & 35.5 & 37.0 & 0.10 & 0.52 \\
\hline Viscera & 0.32 & 66.6 & 63.4 & 0.06 & 0.25 & 2.57 & 395 & 409 & 0.18 & 2.07 \\
\hline \multirow[t]{2}{*}{ Body } & 0.59 & $50.0^{-1}$ & 44.6 & $0.05^{-}$ & 0.22 & 2.10 & $134^{-}$ & 139 & 0.13 & 0.84 \\
\hline & \multicolumn{5}{|c|}{ Razorbill $($ Alca torda $)(\mathrm{n}=9)$} & \multicolumn{5}{|c|}{ Tufted duck (Aythya fuligula) $(\mathrm{n}=2)$} \\
\hline Liver & 3.86 & 57.2 & 58.2 & 0.71 & 1.28 & 0.16 & 66.9 & 91.1 & 1.64 & 2.86 \\
\hline Muscle & 0.99 & 2.71 & 2.56 & 0.38 & 0.82 & 0.05 & 11.5 & 10.6 & 0.12 & 0.24 \\
\hline Feathers & 2.81 & 116 & 101 & 0.29 & 2.78 & 0.47 & 98.6 & 96.3 & 0.32 & 0.89 \\
\hline Skeleton & 0.59 & 15.4 & 12.5 & 0.50 & 1.55 & 1.24 & 63.0 & 63.0 & - & - \\
\hline Skin & 0.66 & 19.1 & 17.0 & 0.29 & 1.36 & 0.10 & 30.6 & 30.2 & 0.23 & 0.39 \\
\hline Viscera & 1.43 & 46.6 & 48.3 & 0.52 & 1.12 & 1.48 & 919 & 921 & 0.15 & 1.66 \\
\hline \multirow[t]{2}{*}{ Body } & 1.22 & 31.4 & 28.5 & 0.41 & 1.44 & 0.69 & 220 & 221 & - & - \\
\hline & \multicolumn{5}{|c|}{ Common eider (Somateria mollissima) $(\mathrm{n}=13)$} & \multicolumn{5}{|c|}{ Long-tailed duck (Clangula hyemalis) $(\mathrm{n}=13)$} \\
\hline Liver & 2.92 & 9.42 & 9.04 & 0.18 & 0.48 & 18.90 & 14.4 & 14.0 & 0.38 & 1.52 \\
\hline Muscle & 1.24 & 7.80 & 7.00 & 0.05 & 0.48 & 2.30 & 11.6 & 10.1 & 0.40 & 0.80 \\
\hline Feathers & 2.78 & 259 & 232 & 0.29 & 2.87 & 2.59 & 168 & 156 & 0.24 & 1.35 \\
\hline Skeleton & 0.51 & 138 & 126 & 0.52 & 1.86 & 1.98 & 42.7 & 39.5 & 0.65 & 4.31 \\
\hline Skin & 0.83 & 47.1 & 42.0 & 0.04 & 0.11 & 5.16 & 63.6 & 60.2 & 0.37 & 1.49 \\
\hline Viscera & 0.82 & 293 & 260 & 0.05 & 1.22 & 2.59 & 89.0 & 84.7 & 0.05 & 1.46 \\
\hline \multirow{2}{*}{ Bodv } & 1.15 & 127 & 113 & 0.20 & 1.16 & 3.54 & 60.5 & 56.5 & 0.31 & 2.10 \\
\hline & \multicolumn{5}{|c|}{ Velvet scoter (Melanitta fusca) $(\mathrm{n}=12)$} & \multicolumn{5}{|c|}{ Black guillemot (Cepphus gryle) $(\mathrm{n}=2)$} \\
\hline Liver & 4.62 & 11.9 & 17.2 & 0.15 & 0.65 & 6.30 & 25.9 & 32.4 & 0.42 & 1.70 \\
\hline Muscle & 0.73 & 6.8 & 7.07 & 0.53 & 1.44 & 1.54 & 50.3 & 144 & 0.04 & 0.40 \\
\hline Feathers & 3.72 & 83.0 & 78.5 & - & - & 4.05 & 271 & 279 & 0.24 & 3.40 \\
\hline Skeleton & 3.17 & 12.3 & 11.3 & 0.10 & 0.59 & 1.89 & 30.3 & 41.9 & 0.08 & 0.40 \\
\hline Skin & 0.82 & 40.7 & 38.3 & 0.08 & 0.80 & 0.41 & 62.9 & 61.4 & 0.26 & 0.47 \\
\hline Viscera & 1.36 & 130 & 118 & 1.81 & 4.0 & 1.96 & 55.4 & 54.3 & 0.50 & 4.25 \\
\hline \multirow[t]{2}{*}{ Bodv } & 2.00 & 42.1 & 39.4 & & & 2.13 & 75.7 & 100 & 030 & 136 \\
\hline & \multicolumn{5}{|c|}{ Red-throated diver (Govia stellata) $(\mathrm{n}=7)$} & \multicolumn{5}{|c|}{ Common guillemot (Uria aalge) $(\mathrm{n}=2)$} \\
\hline Liver & 3.67 & 4.21 & 4.02 & 0.43 & 0.79 & 1.23 & 83.1 & 88.8 & 0.23 & 1.38 \\
\hline Muscle & 0.31 & 4.52 & 4.17 & 0.19 & 0.48 & 0.07 & 4.20 & 5.60 & 0.12 & 0.23 \\
\hline Feathers & 1.05 & 140 & 122 & 0.22 & 1.76 & 2.92 & 157 & 136 & 0.40 & 1.24 \\
\hline Skeleton & 0.42 & 9.85 & 7.85 & 0.19 & 1.69 & 0.57 & 10.4 & 11.1 & 0.19 & 0.38 \\
\hline Skin & 0.33 & 33.0 & 28.3 & 0.52 & 1.11 & 0.15 & 24.4 & 23.9 & 0.10 & 0.30 \\
\hline Viscera & 1.56 & 127 & 125 & 0.45 & 1.22 & 0.31 & _56.1 & 102 & 0.34 & 0.68 \\
\hline Body & 0.74 & 43.2 & 39.3 & 0.30 & 1.16 & 0.59 & 32.6 & 34.4 & 0.18 & 0.47 \\
\hline
\end{tabular}


${ }^{238} \mathrm{Pu}$ and ${ }^{239+240} \mathrm{Pu}$

All results of ${ }^{238} \mathrm{Pu}$ and ${ }^{239+240} \mathrm{Pu}$ plutonium concentrations are presented in Table 1 . The obtained results indicated that the plutonium is non-uniformly distributed in organs and tissues of analyzed seabirds. Generally the highest plutonium concentrations were found in the digestion organs, skeleton and feathers. Among analyzed birds the highest ${ }^{239+240} \mathrm{Pu}$ concentration was found in skeleton, its activities in this tissue ranged from $0.05 \mathrm{mBq} \mathrm{kg}^{-1} \mathrm{ww}$ in great cormorant to $4.31 \mathrm{mBq} \mathrm{kg}^{-1} \mathrm{ww}$ in long-tail duck (Tab. 1). The concentrations of ${ }^{239+240} \mathrm{Pu}$ in seabirds are lower in comparison to fish from the southern Baltic Sea as well as in comparison to phytobenthos, crustaceans and bivalves (Strumińska-Parulska and Skwarzec, 2010). Generally we observed higher ${ }^{239+240} \mathrm{Pu}$ concentrations in whole body of wintering seabirds (long-tailed duck, black guillemot, common eider) and further in migratory seabirds (razorbill, common guillemot, red-throated diver). These birds had also the highest ${ }^{239+240} \mathrm{Pu}$ concentrations in feathers, viscera and skeleton. Permanently residing in the southern Baltic Sea seabirds were characterized by the highest plutonium concentrations in liver (great cormorant, tufted duck). Detailed diet analysis and organs of ${ }^{239+240} \mathrm{Pu}$ accumulation allowed for statement that both inhalation and food play a significant role in its supply. Bird which eat fish (great cormorant, common guillemot) are characterized by much lower ${ }^{239+240} \mathrm{Pu}$ concentrations in analyzed organs and tissues similarly as their food - fish (Skwarzec, 1995). ${ }^{239+240} \mathrm{Pu}$ concentrations in feathers, skeleton and viscera were lower within only fish-eating birds (great cormorant, common guillemot) in comparison to birds which feed with bivalves, crustaceans or phytobenthos (eurasian coot, razorbill, black guillemot, red-throated diver). These results confirm previous research that fish-eating birds are characterized by lower concentrations of radionuclides in comparison to omnivores (higher concentrations) or plant- and larvaeeating birds (the highest concentrations).

\section{Acknowledgments}

The authors would like to thank the Ministry of Science and Higher Education for the financial support under grant DS/8120-4-0176-12.

\section{References}

Boryło A, Skwarzec J, Fabisiak J. Bioaccumulation of uranium ${ }^{234} \mathrm{U}$ and ${ }^{238} \mathrm{U}$ in marine birds. J Radioanal Nucl Chem 2010;284:165.

Burger, J, Gochfeld, M. Risk, mercury levels, and birds: relating adverse laboratory effects to field biomonitoring. Environ Res. 1997;75:160.

Salo A, Toumainen K, Voipio A. Inventories of certain long-lived radionuclides in the Baltic Sea. In: Study of Radioactive Materials in the Baltic Sea. IAEATECDOC-362 Vienna; 1986:53.

Skwarzec B. Polon, uran i pluton w ekosystemie południowego Bałtyku. 6. Rozprawy i monografie, IO PAN. Sopot; 1995.

Skwarzec B. Radiochemical methods for the determination of polonium, radiolead, uranium and plutonium in environmental samples. Chem Anal (Warsaw) 1997;42:107.

Skwarzec B. Determination of radionuclides in aquatic environment. In: Analytical measurement in aquatic environments. Tylor\&Francis PE 2009: 241.

Skwarzec B, Strumińska DI, Boryło A. Radionuclides of iron $\left({ }^{55} \mathrm{Fe}\right)$, nickel $\left({ }^{63} \mathrm{Ni}\right)$, polonium $\left({ }^{210} \mathrm{Po}\right)$, uranium $\left({ }^{234} \mathrm{U},{ }^{235} \mathrm{U},{ }^{238} \mathrm{U}\right)$ and plutonium $\left({ }^{238} \mathrm{Pu},{ }^{239+240} \mathrm{Pu}\right.$, ${ }^{241} \mathrm{Pu}$ ) in Poland and Baltic Sea environment. Nukleonika 2006;Suppl.2:45.

Skwarzec B, Fabisiak J. Bioaccumulation of polonium ${ }^{210} \mathrm{Po}$ in marine birds. J Environ Radioact 2007;93:119.

Strumińska-Parulska DI, Skwarzec B. Plutonium isotopes ${ }^{238} \mathrm{Pu},{ }^{239+240} \mathrm{Pu},{ }^{241} \mathrm{Pu}$ and ${ }^{240} \mathrm{Pu} /{ }^{239} \mathrm{Pu}$ atomic ratios in southern Baltic Sea ecosystem. Oceanologia 2010;52(3):499.

Strumińska-Parulska DI, Skwarzec B, Fabisiak J. Plutonium bioaccumulation in seabirds. J Environ Radioact 2011;102:1105.

Tomiałojć L, Stawarczyk T. Awifauna Polski.

Rozmieszczenie, liczebność i zmiany. PTPP "pro

Natura". Wrocław 2003.

Tutu H, Cukrowska EM, Dohnal V, Havel J. Application of artificial neural networks for classification of uranium distribution in the Central Rand goldfield, South Africa. Environ Model Assess 2005;10:43. 